\title{
Basophil response to peanut allergens in the mediterranean area
}

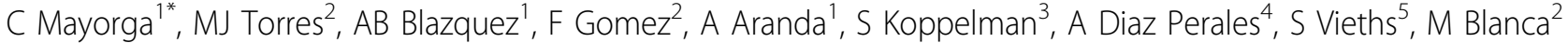 \\ From Food Allergy and Anaphylaxis Meeting (FAAM 2013) \\ Nice, France. 7-9 February 2013
}

\section{Background}

The major peanut allergens Arah1, Arah2, and Arah3 are considered the more important sensitizers in peanut allergy, although the lipid transfer protein (LTP) Arah9 has been shown relevant in Mediterranean areas. We evaluated the basophil activation response (BAT) to different peanut allergens and the peach LTP Prup3 in patients with peanut allergy.

\section{Methods}

We included 60 subjects in different groups: Group 1, peanut and peach allergy; Group 2, peanut allergy and good tolerance to peach; Group 3, peach allergy and good tolerance to peanut; Group 4, good tolerance to peach and peanut. The diagnostic was performed by clinical history, skin prick test and/or double blind placebo controlled food challenge. BAT to Arah1, Arah2, Arah3, Arah6, rArah9 and rPrup3 was done using antiIgE and CD63 and cells analyzed in a FACSCalibur flow cytometer.

\section{Results}

Comparisons of BAT results between peanut allergic patients (Group 1 and 2) and controls (Group 4) showed increased basophil activation in Group 1 with Arah2 $(\mathrm{p}=0.031)$ and Prup3 $(\mathrm{p}=0.009)$ whereas Group 2 had an increase with Arah1 ( $\mathrm{p}=0.016)$, Arah2 $(\mathrm{p}=0.001)$ and Arah9 $(\mathrm{p}=0.016)$, but not with Prup3. Comparisons with subjects allergic to peach with good tolerance to peanut (Group 3) showed a BAT increase only with Arah2 ( $\mathrm{p}=0.009)$ in Group 2. Finally, the comparisons between groups with good tolerance to peanut (Groups 3 and 4) showed significant differences for peach allergic patients with Arah9 ( $\mathrm{p}=0.004)$ and Prup3 $(\mathrm{p}=0.008)$.

${ }^{1}$ Resarch Laboratory, IMABIS Foundation-Carlos Haya Hospital/Bionand, Malaga, Spain

Full list of author information is available at the end of the article

\section{Conclusion}

The peanut allergen Arah2 is the best to discriminate peanut allergy in a Mediterranean population where LTP is highly prevalent.

\section{Disclosure of interest}

None declared.

\section{Author details}

'Resarch Laboratory, IMABIS Foundation-Carlos Haya Hospital/Bionand, Malaga, Spain. ${ }^{2}$ Allergy Service, Carlos Haya Hospital, Malaga, Spain. ${ }^{3} \mathrm{HAL}$ Allergy, HAL Allergy, Leiden, the Netherlands. ${ }^{4}$ Centre for Plant Biotechnology and Genomics, UPM-INIA, Pozuelo de Alarcon, Spain. ${ }^{5}$ Division of Allergology, Paul-Ehrlich-Institut, Federal Institute for Vaccines and Biomedicines, Landen, Germany.

Published: 25 July 2013

doi:10.1186/2045-7022-3-S3-P167

Cite this article as: Mayorga et al.: Basophil response to peanut allergens in the mediterranean area. Clinical and Translational Allergy 2013 3(Suppl 3):P167.

Submit your next manuscript to BioMed Central and take full advantage of:

- Convenient online submission

- Thorough peer review

- No space constraints or color figure charges

- Immediate publication on acceptance

- Inclusion in PubMed, CAS, Scopus and Google Scholar

- Research which is freely available for redistribution

\section{Ciomed Central}

